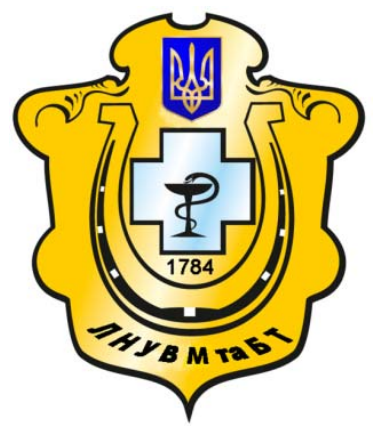

Науковий вісник Львівського національного університету ветеринарної медицини та біотехнологій імені С.3. Гжицького

Scientific Messenger of Lviv National University of Veterinary Medicine and Biotechnologies named after S.Z. Gzhytskyj

doi:10.15421/nvlvet7504

ISSN 2519-268X print

ISSN 2518-1327 online

$\underline{\text { http://nvlvet.com.ua/ }}$

УДК 378.1

\title{
Методика комп'ютерного моделювання та анімації будівництва індивідуального житлового будинку на схилах для навчального процесу у вишій школі
}

\author{
І.Г. Свідрак ${ }^{1}$, В.І. Топчій ${ }^{1}$, М.П. Кушинов ${ }^{1}$, О.Р. Максисько ${ }^{2}$ \\ svidraki@mail.ru, Vladislav.I.Topchii@Lpnu.ua, maxim.kushinov@jmail.com, \\ ${ }^{1}$ Наиіональний університет «Львівська політехніка», \\ вул. С. Бандери, 12, м. Львів, 79013, Україна; \\ ${ }^{2}$ Львівський національний університет ветеринарної медицини та біотехнологій імені С.3. Гюииького, \\ вул. Пекарська, 50, м. Львів, 79010, Украӥна
}

\begin{abstract}
Стаття присвячена опрацюванню методики моделювання індивідуального житлового будинку на схилах та створення анімаційних послідовностей для презентаційних переглядів в середовищі графічної системи АитоСАD. Характерною ознакою розвитку сучасної будівельної індустрії є застосування на стадії розробки систем комп'ютерного проектування (САПР). Вивчення та засвоєння студентами графічної системи AиtoCAD, яка є однією із поширеніших комп'ютерних систем інженерного рівня, базується, зокрема, на методичному забезпеченні лабораторних та практичних занять з інженерної та комп'ютерної графіки. Адже в умовах інформачійного суспільства навчальний процес повинен проходити як засіб професійного розвитку студентів, а головне завдання освіти - створення умов для самоосвіти, пов'язаної з розвитком творчого та критичного мислення студента при наявності певної кількості знань та навичок, необхідних майбутньому спеціалістові. Тенденція до зменшення кількості аудиторних годин у ВШ вимагає самостійного опрачювання студентами багатьох тем по спеціальності. Багато з напрямків досліджень, які надаються студентам на самоопрацювання, пов'язані з розв'язанням складних інженерних завдань. Актуальною розробкою для районів із змінним рельєфом є будівництво на схилах. В статті розглянуто особливості такого будівництва та підходи до проектування будівлі з використанням найсучасніших методів моделювання та новітніх технологій у будівництві. Результати представленої роботи покладені в основу одного з розділів навчально-методичного посібника для студентів інженерно-будівельного напрямку підготовки з курсу інженерної та комп 'ютерної графіки, який дозволить набути теоретичних знань та відпрачювати методику моделювання житлових будинків на схилах в середовиші системи AиtоCAD.

Ключові слова: комп'ютерне моделювання, графічний редактор, системи комп 'ютерного проектування, АиtоСАD, методика викладання, візуалізачія, тривимірне моделювання, анімація, будівництво на схилах, вертикальне планування ділянки, ландшафтне вирішення.
\end{abstract}

\section{Методика компьютерного моделирования и анимации строительства индивидуального жилого дома на склонах для учебного процесса в высшей школе}

\author{
И.Г. Свидрак ${ }^{1}$, В.И. Топчий ${ }^{1}$, М.П. Кушинов ${ }^{1}$, О.Р. Максисько ${ }^{2}$ \\ svidraki@mail.ru, Vladislav.I.Topchii@Lpnu.ua,maxim.kushinov@jmail.com, \\ ${ }^{1}$ Национальный университет «Львовская политехника», \\ ул. С. Бандеры, 12, г. Львов, 79013, Украина; \\ ${ }^{2}$ Львовский национальный университет ветеринарной медицины и биотехнологий имени С.з. Гжиикого, \\ ул. Пекарская, 50, г. Львов, 79010, Украина
}

Citation:

Svidrak, I.H., Topchiy, V.I., Kushynov, M.P., Maksysko, O.R. (2017). Method of computer modeling and animating of individual houses' constructing process on the slopes. Scientific Messenger LNUVMBT named after S.Z. Gzhytskyj, 19(75), 19-22. 
Статья посвящуена обработке методики моделирования индивидуального жилого дома на склонах и создания анимационных последовательностей для презентационных просмотров в среде графической системы АитоСАD. Характерной особенностью развития современной строительной индустрии является применение на стадии разработки систем компьютерного проектирования (САПР). Изучение и усвоение студентами графической системь АитоСАD, которая является одной из распространенных компьютерных систем инженерного уровня, базируется, в частности, на методическом обеспечении лабораторных и практических занятий по инженерной и компьютерной графике. Ведь в условиях информационного общества учебный прочесс должен проходить как средство профессионального развития студентов, а главная задача образования - создание условий для самообразования, связанных с развитием творческого и критического мылиления студентов при наличии определенного количества знаний и навыков, необходимых будущему специалисту. Тенденция к уменьшению количества аудиторных часов в ВШ требует самостоятельной работы студентов многих тем по специальности. Многие из направлений исследований, которые предоставляются студентам на самостоятельное изучение, связаннье с решением сложных инженерных задач. Актуальной разработкой для районов с переменным рельефом является строительство на склонах. В статье рассмотрень особенности такого строительства и подходы к проектированию здания с использованием самых современных методов моделирования и новейтих технологий в строительстве. Результаты представленной работы положены в основу одного из разделов учебно-методического пособия для студентов инженерностроительного и архитектурного направлений подготовки по курсу инженерной и компьютерной графики, которьй позволит приобрести теоретические знания и отработать методику моделирования жильх домов на склонах в среде системь AutoCAD.

Ключевые слова: компьютерное моделирование, графический редактор, системы компьютерного проектирования, АитоСАD, методика преподавания, визуализация, трехмерное моделирование, анимация, строительство на склонах, вертикальная планировка участка, ландшафтное решение.

\title{
Method of computer modeling and animating of individual houses' constructing process on the slopes
}

\author{
I.H. Svidrak ${ }^{1}$, V.I. Topchiy ${ }^{1}$, M.P. Kushynov ${ }^{1}$, O.R. Maksysko ${ }^{2}$ \\ svidraki@mail.ru, Vladislav.I.Topchii@Lpnu.ua,maxim.kushinov@jmail.com, \\ ${ }^{I}$ National University «Lviv Polytechnic» \\ S. Bandera Str., 12, Lviv, 79013, Ukraine; \\ ${ }^{2}$ Lviv national university of veterinary medicine and biotechnologies named after S. Gzhytskyj, \\ Pekarska Str., 50, Lviv, 79010, Ukraine
}

\begin{abstract}
The article is devoted to processing techniques of modeling individual apartment house on the slopes and create animated sequences for presentation of views among the graphic system AutoCAD. A characteristic feature of the modern construction industry is the use of under development of computer-aided design (CAD). Learning and mastering graphic system AutoCAD, which is one of the more common computer systems engineering level is based in particular on methodological provision of laboratory and practical training in engineering and computer graphics. Indeed, in the information society the learning process should take place as a means of professional development of students as the main task of education - creating conditions for self-education related to the development of creative and critical thinking of the student in the presence of a certain amount of knowledge and skills required of future specialists. The trend to reduce the number of classroom hours required HS student independent study many subjects in the specialty. Many areas of research that are provided to students selfwork related solving complex engineering problems. The actual development for areas with varying topography is building on the slopes. In the article the features of the building and approaches to designing buildings using advanced modeling techniques and new technologies in construction. The results are the basis of one of the sections of a manual for students of Civil Engineering course towards preparation of engineering and computer graphics, which will acquire theoretical knowledge and work methodology for modeling of residential buildings on the slopes in the environment of AutoCAD.
\end{abstract}

Key words: computer modeling, image editor, system of computer-aided design, AutoCAD, methods of teaching, visualization, three-dimensional modeling, animation, building on the slopes, vertical planning area, landscape solution.

\section{Вступ}

Будівельний майданчик на схилі - одночасно і проблема, і вигода. Проблемними є те, що вартість та складність проекту відчутно зростає. Вигода в тому, що, по завершенні будівництва, ви маєте набагато цікавішу будівлю. Існує велика кількість параметрів, які слід врахувати при будівництві на схилах. Найпершим, очевидно, є крутизна та напрям схилу. Залежно від типу схилу по відношенню до вулиці, існують різні варіанти проектування будівель. Оскільки вартість земляних та супутніх робіт $є$ доволі високою, досвідчений інженер повинен мінімізувати витрати, розробивши проект будинку, що максимально повторюватиме контури ландшафту, чого можна досягнути методами різнорівневого проектування, коли будівля максимально охоплює схил. Саме тому необхідно надзвичайно відповідально підходити до проектування будівлі з урахуванням особливостей місцевості, використовуючи найсучасніші методи моделювання та проектування, а також новітні технології будівництва.

Метою роботи є опрацювання методики та підготовка змістового матеріалу для розробки методичних вказівок з курсу комп'ютерної графіки «Моделювання індивідуальних житлових будинків на схилах» для 
студентів інженерно-будівельних та архітектурних напрямків підготовки. В ході виконання роботи була поставлене завдання поєднати в єдине ціле логіку послідовності спорудження житлового будинку на схилі та комплекс інструментальних засобів AutoCad для побудови та візуалізації відповідних поверхонь, планування рельєфу та об'єктів будівельної споруди. Кінцеве завдання після візуалізації полягало у створенні засобами графічної системи відеофільму, який дозволяв би за допомогою анімації оглянути периметр будинку та прилеглу територію по наперед заданій траекторії руху відеокамери з метою презентаційного представлення результатів роботи.

На сьогоднішній день немає єдиного джерела загальної інформації щодо проектування споруд на схилах, яке б наділило студентів архітектурнобудівельних спеціальностей базовими знаннями у цій сфері. Використання системи AutoCad при створенні тривимірних моделей дозволяє спростити інтегрування методики у вже наявні навчальні програми спеціалізованих закладів освіти.

\section{Матеріал і методи дослідження}

Існує велика кількість параметрів, які слід врахувати при проектуванні і подальшому зведенні будинку на схилі.

Залежно від типу схилу по відношенню до вулиці, існують різні варіанти проектування будівель. Тип проектування, при якому схил спадає зі сторони вулиці (від головного фасаду), називається спадаючим; такий, коли схил зростає з тилу до фасаду будівлі, називається підйомним; коли схил зростає/спадає по краях будівлі - бічний; якщо схил змінюється у двох напрямках, такий тип називається множинним (Sloping Sites...). Зі спадаючими схилами доволі легко працювати, у той час як будівництво на підйомному схилі потребуватиме набагато більшого об'єму земельних робіт та улаштування підпірних стін.

Будівництво будинку на схилі значною мірою залежить від крутизни останнього. Майданчики 3 невеликим ухилом, що не перевищує $3 \%$, можна розглядати, як рівні, і будівлі на них можна зводити по типових проектах. Також по типових проектах можуть бути зведені і будинки на ділянках з малим ухилом до 7\%, але вони повинні бути без підвалів. Спорудження цокольних поверхів стає доцільним, коли ухил перевищує 8\%. У цьому випадку майданчик не вирівнюється повністю, а під цоколь вирізається частина земельного масиву. Будинок на крутому схилі в 15-20\% дає можливість зведення багатоярусної споруди 3 окремими входами на кожен ярус (Morozov, 2003).

Розміщення будівель і споруд при плануванні і будівництві населених пунктів безпосередньо пов'язано 3 характером рельєфу місцевості. Правильне врахування даних особливостей полегшує прийняття проектних рішень, зменшує вартість будівельних робіт, забезпечує сприятливі умови для розміщення будівель, елементів благоустрою. Виправлення рельєфу 3 метою пристосування його для потреб експлуатації називається вертикальним плануванням (Sokhnych, 2010).

Якщо виконується виїмка грунту, навколишній грунт повинен бути закріплений. Закріплення виконують за допомогою спеціально спроектованих стін, які мають бути міцними та водонепроникними. Будьяка виїмка, глибша від 1 метра, потребує встановлення підпірних стін. Чим більша глибина виїмки, тим міцнішою та вищою повинна бути підпірна стіна. Стандартна підпірна стіна має потужний фундамент для попередження відхилень стіни під тиском грунту позаду стіни.

Організації водовідвідної системи слід приділити належну увагу. Чим більший перепад висот, тим вища ймовірність руйнування схилу. Дренаж дозволить регулювати водний баланс, забезпечить швидке відведення води, що утворюється після опадів або танення снігу (Samoilov and Levadnii, 2009).

При проектуванні необхідно врахувати підвищену небезпеку зсувів, а отже варто приділити належну увагу засобам підсилення схилів та фундаментів. Переважну більшість основ складають слабкі грунти (лесові просадочні, заторфовані, замулені, насипні, намивні, набухаючі грунти, мули, торфи) (Shvets, 2014). Проектувальники звичайно застосовують найбільш прості та типові принципові схеми підсилення фундаментів будівель і споруд. Підсилення основ виконують за допомогою різних фізико-хімічних процесів, до яких належать методи, які полягають у нагнітанні в основу розчину в'яжучих речовин.

Для презентаційних представлень створена в середовищі графічної системи AutoCAD спрощена поетапна комп'ютерна модель житлового будинку на схилі з подальшою оглядовою анімацією. В цьому контексті розглянуто: моделювання схилу, будівельного майданчика, підпірної стінки, фундаменту будинку та самого житлового будинку.

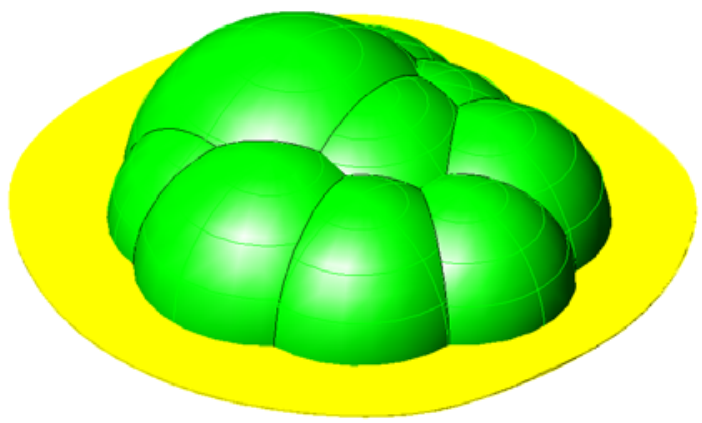

Рис. 1. Моделювання схилу

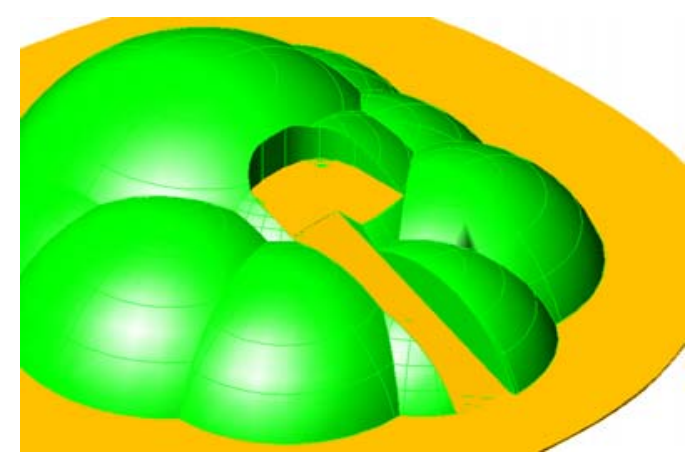

Рис. 2. Моделювання будівельного майданчика 


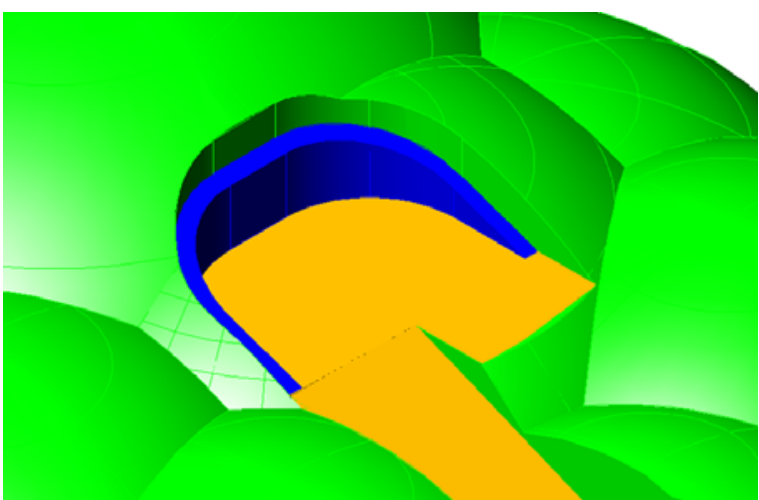

Рис. 3. Моделювання підпірної стінки

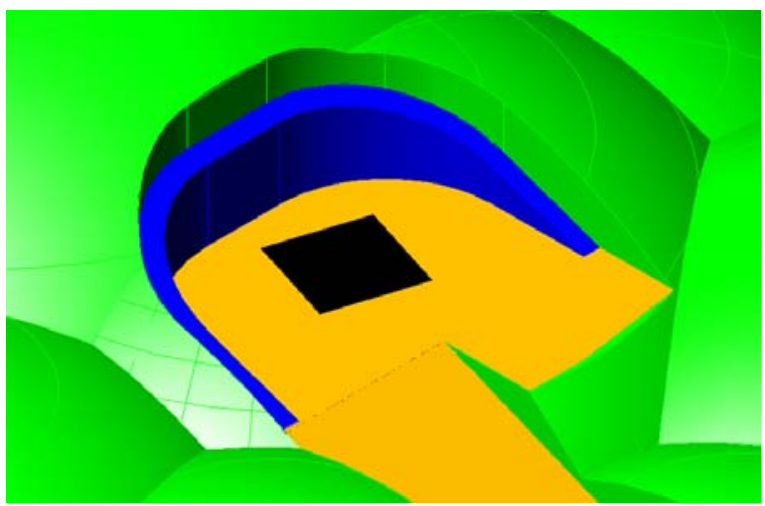

Рис. 4. Моделювання фундаменту будинку

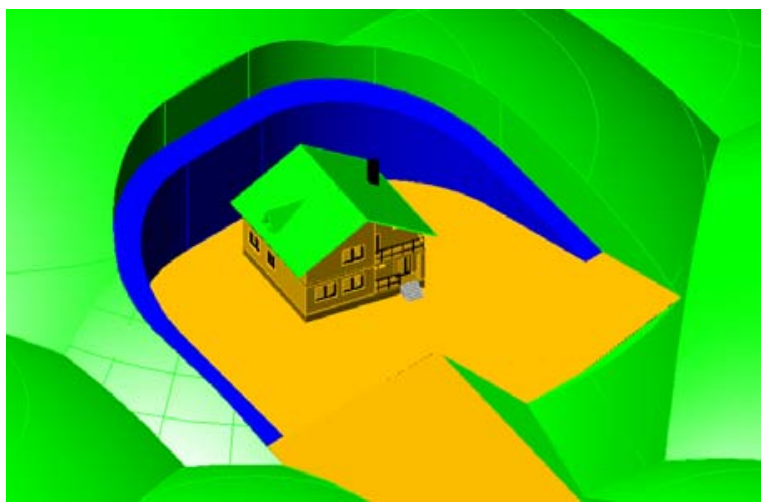

Рис. 5. Моделювання житлового будинку

\section{Результати та їх обговорення}

У роботі досліджені способи проектування та будівництва будинку на схилі. Розглянуті усі особливості розміщення та планування споруди, пов'язані із змінним рельєфом. Для візуалізації застосовувався інструментарій системи AutoCad для 3D моделювання. Послідовність геометричних побудов споруди була прив'язана до відповідних кроків технології реального будівництва. Така покрокова технологія побудови дає можливість у повному обсязі засвоїти як спеціалізовані команди AutoCad так і технологічну та конструктивну схеми побудови індивідуального житлового будинку на схилі.

\section{Висновки}

Для досконального володіння студентами сучасними знаннями, професійними уміннями та навичками, необхідно безперервно удосконалювати систему навчання, шукати шляхи підвищення іiі ефективності, впроваджувати інтерактивні методи навчання, постійно оновлювати методичну базу, підвищувати рівень комп'ютерної підготовки майбутніх спеціалістів 3 використанням відповідного програмного забезпечення. Результати представленої роботи покладені в основу одного з розділів навчально-методичного посібника для студентів інженерно-будівельного факультету з курсу інженерної та комп'ютерної графіки, який дозволить студентам набути теоретичних знань по спеціальності та відпрацювати методику моделювання житлових будинків на схилах в середовищі системи AutoCAD.

Перспективи подальших досліджень. Удосконалювати методично-навчальну базу для студентів інженерно-будівельного та архітектурного напрямків підготовки, застосовуючи детальніше вивчення інструментальних засобів графічної системи AutoCad та інших профільних графічних редакторів.

\section{Бібліографічні посилання}

Shvets, V.B. (2014). Mekhanika gruntiv. Osnovy i fundamenty. [Foundations' mechanics. Footings and foundations]. Dnipropetrovsk: Porogi (in Ukrainian).

Samoilov, V.S., Levadnii, V.S. (2009). Drenazh i ochistka stochnykh vod. [Draining and refining of wastewater]. Samara: Adelant (in Russian).

Khimchenko, Iu.Ie. (2012). Pidsylennia osnov fundamentiv budivel i sporud za burozmishuvalnoiu tekhnolohiieiu. [Strengthening the footing of foundations using deep soil mixing technology]. Scientific bulletin of PoltNTU. 4(34) T2. Poltava: PoltNTU (in Ukrainian).

Morozov, Ie.O. (2003). Konspekt lektsii z dystsypliny «Planuvannia mist» dlia studentiv budivelnykh spetsialnostei. [Lecture notes on subject «city planning» for students of building specialities]. Dnipropetrovsk: DNURT (in Ukrainian).

Sloping Sites: Your guide to building a house (Tweed Shire Council). Retrieved from URL: https://www.tweed.nsw.gov.au/Download.aspx?Path= /Documents/Planning/TSC02931_Fact_Sheet_4_Wo rking_with_Sloping_Sites.pdf

Sokhnych, A.Ia. (2010). Planuvannia vykorystannia zemel naselenykh punktiv: planuvannia, zabudova i blahoustrii silskykh naselenykh punktiv. [Planning the using of land for settlements: designing, constructioning and improvement of rural settlements]. Lviv: LihaPres (in Ukrainian).

Стаття надійшла до редакиї 3.03.2017 